\title{
INDIVIDUAL AND CONTEXTUAL VARIABLES IN EFL RECEPTIVE VOCABULARY: ANALYSIS OF GENDER EFFECT AND MOTIVATION OF CLIL PRIMARY GRADERS $^{13}$
}

\author{
Almudena Fernández Fontecha, Universidad de La Rioja \\ Email: almudena.fernandez@unirioja.es ${ }^{14}$
}

\begin{abstract}
This paper caters for some insights into the influence of $6^{\text {th }}$ graders' gender and motivation on their knowledge of receptive vocabulary in EFL in CLIL. This study delves into learners' gender variation in EFL receptive vocabulary size and in motivation types towards EFL, and it explores the connection between learners' motivation towards EFL and their receptive vocabulary size. No statistically significant results are found on gender differences in vocabulary size. Females are significantly more intrinsically motivated than males. No correlation is identified between receptive vocabulary size and intrinsic and extrinsic motivation. The effect of CLIL is discussed here, among others. Keywords: Motivation; receptive vocabulary size; gender; Content and Language Integrated Learning (CLIL); English as a Foreign Language (EFL).
\end{abstract}

Título en español: "Variables individuales y contextuales en el vocabulario receptivo de Inglés como lengua extranjera: análisis del efecto del género y la motivación en alumnos AICLE de primaria".

Resumen: Este estudio explora posibles diferencias según la variable género en el tamaño del vocabulario receptivo de alumnos de $6^{\circ}$ de educación primaria y sus niveles de motivación hacia el inglés como lengua extranjera. Asimismo, explora la conexión entre dicha motivación y el número de palabras que se conocen receptivamente. No hay diferencias entre chicos y chicas en los resultados de vocabulario receptivo. Las chicas están intrínsicamente más motivadas que los chicos. No hay correlación entre el número de palabras que chicos y chicas conocen receptivamente y los tipos de motivación. El efecto de AICLE en los resultados, entre otros, es objeto de discusión.

Palabras clave: Motivación; tamaño de vocabulario receptivo; género; Aprendizaje Integrado de Contenidos y Lengua Extranjera (AICLE); Inglés como Lengua Extranjera.

\footnotetext{
13 Date of reception: 15 July 2014

Date of acceptance: 30 August 2014

14 This study is part of the research project "Factores individuales y contextuales en la adquisición y desarrollo de la competencia léxica en inglés como lengua extranjera" funded by the Spanish Ministerio de Ciencia e Innovación (Grant Ref. N: FFI2010-19334/FILO).
} 


\section{INTRODUCTION}

Content and Language Integrated Learning (CLIL) has experienced a growth in the European context over the last two decades. CLIL is a dual-focused approach that involves the combined learning of a subject and a foreign language in a wide variety of practices and under diverse contexts and circumstances. Ever since the term emerged in the European context in the mid 1990s, CLIL has by far succeeded in drawing the attention from different circles. Researchers have shown an increased interest in CLIL and have addressed foreign or second language topics that cover all educational levels, language components and language skills (e.g., Dalton-Puffer, Nikula and Smit 2010; Dalton-Puffer and Smit 2007; Fortanet-Gómez 2013; Llinares, Morton and Whittaker 2012; Ruiz de Zarobe and Jiménez Catalán 2009). In this type of instruction, affective and attitudinal variables, such as motivation, have a major role as CLIL seeks to achieve learners' engagement in meaningful forms of using languages.

In this study, we attempt to delve into gender differences in EFL receptive vocabulary size and types of motivation towards EFL in a group of $6^{\text {th }}$ CLIL graders. In the next lines, we will provide the state of the art for these issues.

\subsection{Individual and contextual variables in EFL receptive vocabulary: motivation, gender and CLIL}

Language learners' motivational profiles are an important area in the study of foreign language learning (Anglada and Banegas 2012; Dörnyei and Ushioda 2009; Gabryś-Barker and Bielska 2013; Lasagabaster 2003). From Gardner and Lambert's (1972) Socio-Psychological model, several models have attempted to shed light on the relationship between motivation and language learning (e.g., Self-Determination Theory by Deci and Ryan 1985; Noels, Pelletier, Clément and Vallerand 2000; or more recently the L2 Motivational Self System by Dörnyei 2005, 2009). These models point to extrinsic and intrinsic reasons by which we learn languages. For example, in Gardner and Lambert's model, instrumental orientation refers to the desire to command the foreign language due to external reasons, such as getting a job, and integrative orientation addresses the ultimate goal of learning a language. On its part, according to the Self-Determination Theory, there are two types of motivation, intrinsic and extrinsic, which, respectively, address internal and external factors that drive motivation. Although some parallelism can be established between motivation types of the models, they differ to a certain extent. What is relevant here is to note that, independently of the model, motivation and foreign language learning generally correlate positively (Bernaus and Gardner 2008; Csizér and Dörnyei 2005; Yu and Watkins 2008).

Individual and contextual variables are usually addressed in studies on motivation and language learning. Among the individual variables, gender is particularly considered. In general, females surpass boys in motivation levels and in the two types of motivation (Dabbagh and Khajehpour 2011; Dörnyei and Csizér 2002; Dörnyei, Csizér and Németh 2006; Henry 2012; Henry and Apelgren 2008), although some exceptions are found (Azarnoosh and Birjandi 2012). With regard to situational or contextual factors, they also seem to affect learners' motivation toward language learning. In CLIL, motivation is of utmost importance as it focuses on creating 
a meaningful context for language learning through cognitively rich activities. However, there is a dearth of empirical studies on motivation and CLIL that provide actual evidence of this interaction, as noted by Bruton (2011, as cited by Cenoz, Genesee and Gorter 2013:14).

In the existing literature, CLIL learners are generally more motivated than non-CLIL learners and a positive relationship is identified between motivation and language learning (Huang 2011, Lasagabaster 2011; Murtagh 2007; Seikkula-Leino 2007). In the results of such a relationship that takes place in a CLIL setting, further variables, such as age, gender or some sociocultural variables, could be having some effect (Doiz, Lasagabaster and Sierra 2014). Cenoz, Genesee and Gorter (2013:14-15) explain that in many cases the students are motivated towards the foreign language before they enroll to CLIL. In other cases, these authors point out students' self-esteem could be negatively affected by the fact that they have to use a foreign language (e.g., Mearns 2012). When gender variation is looked upon in motivation studies, CLIL is proved to have a levelling effect of girls' superiority on motivation (Baker and MacIntyre 2000, Lasagabaster 2014; Merisuo-Storm 2007). In this vein, Lasagabaster and Sierra (2009) concluded that this waning effect is not found in weaker versions of CLIL as girls' motivation levels are higher than boys'.

\subsection{L2 receptive vocabulary knowledge}

In the process of learning a L2 vocabulary, two types of knowledge are distinguished: productive and receptive vocabulary knowledge. Productive vocabulary knowledge addresses the way human beings produce words in order to express their intention both in writing and speaking. Receptive vocabulary knowledge describes word perception and meaning comprehension both in listening and reading (Nation 2001). The number of words that a person knows is referred to as size or breadth. Receptive vocabulary size is often found to correlate with proficiency, hours of L2 exposure and frequency of vocabulary input (Fan 2000; Golberg, Paradis and Crago 2008).

So far there has been little discussion about the relationship between learners' motivation and vocabulary learning. However, the productive-receptive distinction may have some sort of connection with motivation since authors such as Laufer and Paribakht (1998) or Nation (2001) have noted that the requirements of these two processes are different. Vocabulary production is more demanding than reception and involves a sense of wanting to convey a message, a feature not observed in receptive vocabulary learning. A recent line of research originated by Laufer and Hulstijn (2001) has attempted to explore the cognitive load and motivation implied in tasks of vocabulary. It is called the Involvement Load Hypothesis. Based on this hypothesis, a connection is found between motivation and lexical performance (Huang, Eslami and Wilson 2012; Kim 2008). In another vein, some authors have pointed to the complexity of the interaction between these two dynamic processes since motivation is proved to fluctuate as vocabulary learning takes place (Zheng 2012) and vocabulary learning moves cyclically as motivation oscillates (Tseng and Schmitt 2008).

Little is known about gender differences and L2 vocabulary learning (Jiménez Catalán 2010) and about the relationship between motivation and L2 vocabulary learning in a CLIL context. Dalton-Puffer (2011) summarizes the research on some of these variables and found that CLIL contributes to receptive and productive vocabulary learning as well as to 
the learning of more words from low frequency bands and more varied styles. In a study conducted to assess the effectiveness of CLIL on motivation and self-esteem and to test the waning effect of CLIL on gender variation in vocabulary learning, Heras and Lasagabaster (in press) conclude that CLIL reduces gender differences in motivation and it has a positive effect on male and female students' learning of technical vocabulary.

\section{RESEARCH QUESTIONS}

This paper seeks to remedy the lack of research pointed out above on gender differences, motivation and L2 vocabulary learning in a CLIL setting. In particular, it sets out to investigate whether there are any gender differences in a group of CLIL learners regarding (1) EFL receptive vocabulary breadth or size, and (2) motivation towards EFL. It also attempts (3) to explore the relationship between learners' motivation and the number of EFL words they know receptively

\section{METHOD}

\subsection{Participants}

The sample for this study consisted of 66 Spanish-speaking EFL learners of 6th primary graders -38 boys and 28 girls - aged around 11-12 years old. They belonged to an urban middle-class school located in Logroño, La Rioja (Spain). Since the first year in primary education, these students had been following the PILC project (Proyecto de Innovación Lingüística en Centros), a CLIL programme where a subject or part of a subject is taught in the foreign language by a content teacher (Fernández Fontecha, 2010:80). In the community where the study took place the difference in the time of exposure to the foreign language between a CLIL group and a non-CLIL group in 6th year corresponded to the hours in the foreign language that the CLIL group had received via the CLIL subject in addition to the hours that they had been exposed to English in the foreign language class. In this case, during their primary education, this group of students had been exposed to 315 hours of English through the CLIL subject of Natural Sciences and to 629 hours of English via the foreign language class in periods of 3 to 4 hours per week. In sum, at the moment of gathering the data, they had been exposed approximately to 944 hours of instruction in English.

\subsection{Data collection instrument, procedures and analysis}

Schmitt, Schmitt and Clapham's (2001) version 2 of the 2,000-word frequency-band from the receptive version of the Vocabulary Levels Test (2K VLT) (Appendix 1) was used to collect data on learners' receptive vocabulary knowledge. This test consists of words from the frequency list by West (1953) in the General Service List and the Thorndike and Lorge (1944) list. It includes ten groups of six words and three definitions per group. The testees have to match a target word to its definition in 10 minutes. The maximum score is 30 points as correct matching is given one point. In order to calculate the students' receptive vocabulary size, Nation's (1990:78) formula is applied, i.e.: "Vocabulary size = N 
correct answers multiplied by total $\mathrm{N}$ words in dictionary (the relevant word list) divided by $\mathrm{N}$ items in test".

We assessed general motivation together with intrinsic and extrinsic motivation by means of part of a questionnaire adapted from Gardner's (1985) Attitude/Motivation Test Battery (A/MTB) (Appendix 2). It consists of a semantic differential technique of 7-point bipolar rating Likert scale using the following 7 pairs of bipolar adjectives that served to complete the sentence "Considero que el inglés es..." (“I consider English to be..."): 'necessary' / 'unnecessary', 'ugly' / 'nice', 'attractive / ' 'unattractive', 'pleasant' / 'unpleasant', 'important' / 'unimportant', 'useful' / 'useless', and 'interesting'/ 'boring'. These adjectives are introduced with the Spanish phrase Intrinsic motivation is measured through the pairs 'ugly' / 'nice', 'attractive' / 'unattractive', 'pleasant' / 'unpleasant', and 'interesting' / 'boring'; the extrinsic motivation is measured through the pairs 'necessary' / 'unnecessary', 'important' / 'unimportant', and 'useful' / 'useless'. The pair 'difficult' / 'easy' is also included as a distractor since it does not measure motivation. We should note that a simplified version of intrinsic and extrinsic types is used here. That is to say, we only focus on learners' opinions on endogenous factors (intrinsic motivation) and exogenous factors (extrinsic motivation) of learning a foreign language. Other aspects related to motivation remain unconsidered in the present paper.

Finally, we coded the obtained data both from the VLT and the motivation 7-point bipolar rating scale. Later, we analysed them through SPSS (Statistical Package for Social Sciences) (version 19.0).

\section{RESULTS}

RQ 1. Gender variation in EFL receptive vocabulary size

Tables 1 and 2 present the descriptive statistics on 2K VLT and word estimates, respectively, for boys and girls. Boys' mean is slightly superior to girls' but there are not statistically significant differences $(\mathrm{t}(64)=.34, \mathrm{p}=.735$, two-tailed). Word estimates or word size is calculated after applying Nation's (1990:78) formula: "Vocabulary size $=\mathrm{N}$ correct answers multiplied by total $\mathrm{N}$ words in dictionary (the relevant word list) divided by $\mathrm{N}$ items in test". Both groups are near 1,000 words.

\begin{tabular}{lllll}
\hline Groups & Min. & Max. & Mean & SD \\
\hline All & 6 & 23 & 13.86 & 3.77 \\
Males $(\mathrm{n}=38)$ & 6 & 23 & 14.00 & 3.78 \\
Females $(\mathrm{n}=28)$ & 7 & 21 & 13.68 & 3.82 \\
\hline
\end{tabular}

Table 1.2K VLT: descriptive statistics 


\begin{tabular}{lllll}
\hline Groups & Min. & Max. & Mean & SD \\
\hline All & 400 & 1553 & 924.21 & 251.59 \\
Males $(\mathrm{n}=38)$ & 400 & 1553 & 933.34 & 252.28 \\
Females $(\mathrm{n}=28)$ & 467 & 1400 & 911.82 & 254.748 \\
\hline
\end{tabular}

Table 2. Word estimates: descriptive statistics

RQ 2. Gender variation in types of motivation towards the foreign language

We attempt to explore learners' intrinsic (IMot) and extrinsic motivation (EMot). Table 3 displays the descriptive statistics of these two types of motivation per gender. The maximum score for each type of motivation is 7 . An independent-samples t-test was conducted to compare the intrinsic and extrinsic motivation levels for males and females. Females are more intrinsically and extrinsically motivated than males. There was no significant difference in extrinsic motivation levels: EMot: $\mathrm{t}(62)=-.137, \mathrm{p}=.89$, two-tailed) but the difference was statistically significant in IMot for males and females $(\mathrm{t}(60)=-2.17, \mathrm{p}=$ .03 , two-tailed). Figure 1 shows the boxplots with levels in motivation types for gender.

\begin{tabular}{llllll}
\hline Gender & Motivation & Mean & Max. & Min. & SD \\
\hline Males & IMot & 5.17 & 7 & 3.25 & 1.12 \\
$(\mathrm{n}=36)$ & EMot & 6.83 & 7 & 5 & 0.38 \\
Females & IMot & 5.83 & 7 & 3.25 & 1.26 \\
$(\mathrm{n}=26)$ & EMot & 6.84 & 7 & 6 & 0.27 \\
\hline
\end{tabular}

Table 3. Motivation types per gender: descriptive statistics

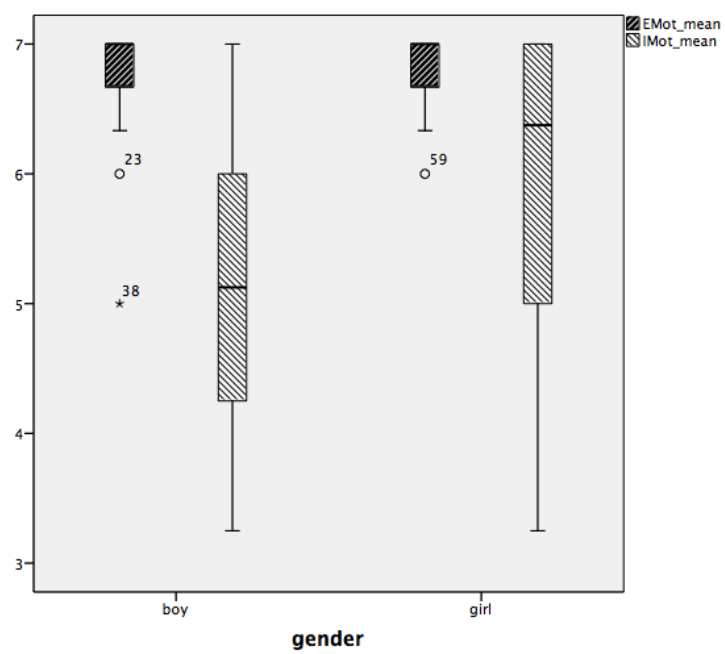

Figure 1. Motivation: males and females' median values

Odisea, $\mathrm{n}^{\circ} 15$, ISSN 1578-3820, 2014, 57-72 
In addition to previous analyses, we performed a Pearson's correlation coefficient to assess the relationship between learners' levels in each type of motivation. As Table 5 shows, no statistically significant correlation between intrinsic and extrinsic motivation in males and females.

\begin{tabular}{lccc}
\cline { 3 - 4 } & & & IMot \\
& & $r$ & $p$ \\
\hline Males & EMot & .161 & .364 \\
Females & Emot & .158 & .441 \\
\hline
\end{tabular}

Table 4. Correlation between IMot and EMot per gender

RQ 3. Relationship between motivation towards EFL and receptive vocabulary size

Pearson's correlation coefficient is applied. As Table 6 indicates, no statistically significant correlation is found neither between 2K VLT and IMot and 2K VLT and EMot.

\section{K VLT}

\begin{tabular}{llcr}
\multirow{3}{*}{ Males } & & $r$ & $p$ \\
& Imot & .04 & .80 \\
\multirow{3}{*}{ Females } & Emot & -.30 & .06 \\
& Imot & .15 & .45 \\
& Emot & .26 & .17 \\
\hline
\end{tabular}

Table 6. Correlation between motivation and 2K VLT

\section{DISCUSSION}

RQ 1. Gender variation in EFL receptive vocabulary size

First, we will discuss on the receptive vocabulary size of both groups globally, without addressing gender variation. The subjects of this study prove to know receptively nearly 1,000 words (mean word estimate: all: 924, males: 933, females: 911). As explained above, in addition to the 629 hours of EFL via the EFL subject, this group of learners had received 315 hours of EFL instruction via CLIL. In order to gain understanding of these findings, we will compare them to results of students in urban middle-class schools with similar sociolinguistic characteristics to ours and located in the same region or close to it. In these studies the $2 \mathrm{~K}$ VLT was used. 
Previous studies on CLIL have reported that this approach fosters receptive vocabulary knowledge (e.g., Jiménez Catalán and Ruiz de Zarobe 2009; Jiménez Catalán, Ruiz de Zarobe and Cenoz 2006). The results reported in this paper do not differ much from the results obtained by a $3^{\text {rd }}$ secondary education $/ 9^{\text {th }}$ grade non-CLIL group in the same region of the present investigation, in a longitudinal study conducted by Agustín Llach and Terrazas Gallego (2012). Similarly to the students of our investigation, the non-CLIL group in the study of these authors had been learning English in the foreign language class in periods of 3 to 4 hours per week and they had been exposed to 944 hours of EFL instruction. They obtained a mean word estimate of 1,206 words. According to these findings, it seems that age, rather than the hours of exposure or type of instruction (CLIL), has a positive effect on the receptive vocabulary size.

The results obtained by the participants of our sample are better than the results obtained by the above-mentioned non-CLIL students in Agustín Llach and Terrazas Gallego's (2012) research when they were in $6^{\text {th }}$ primary education. This group had received approximately 629 hours of English instruction and had obtained a mean word estimate of 663 words in the 2K VLT. Similarly, in a study conducted by Jiménez Catalán and Ruiz de Zarobe (2009) with non-CLIL and CLIL female students from La Rioja and the Basque Country, respectively, who were at their $6^{\text {th }}$ grade at the data collection time, we find that the non-CLIL group's estimates of receptive vocabulary were 602 words. We should take into account that this group had only received an approximate number of 692 hours in English. In order to know if the time of exposure or the type of instruction has a positive impact on the vocabulary size estimates, it is advisable to design studies that compare groups of learners of the same age, who share the same amount of hours of exposure to the foreign language, and who have received different types of instruction (CLIL - no CLIL).

Concerning gender variation in the estimates of vocabulary size, we have identified a quasi-similar performance of males and females in the receptive task. No statistically significant differences were identified. We should note that the number of words known by the girls in our study is superior to the number of words reached by a group of $6^{\text {th }}$ primary education CLIL female learners from the above-mentioned study by Jiménez Catalán and Ruiz de Zarobe (2009). At the data collection time, they had received an approximate number of 960 hours of exposure to English and the estimates of receptive vocabulary were of 800 words versus the 911 words that our female students knew receptively.

So far we have provided examples of the investigation carried out in contexts similar to our study's. We should now account for results found in other studies that took place with non-CLIL students in contexts such as Finland, Germany or Greece, which provide very different figures for students with a fewer number of hours of instruction. The figures that we have obtained are considerably lower than those obtained by Takala (1985) or Milton and Meara (1998). In Takala's (1985) study, a group of secondary graders with 450 hours of instruction in English reached 1,500 mean word estimates. Milton and Meara (1998) conducted research on different groups of secondary learners at level 10 (aged 14-15 years old), such as a group of German students with 400 hours of EFL instruction who knew receptively 1,200 words, or a group of Greek students learning with 660 hours of EFL instruction who proved to know 1,680 words. Although the huge difference between the results of our subjects and the results of the subjects of these studies is large, the comparison 
cannot be easily established. We must be cautious with these findings, as there are some contextual and methodological differences between them. For example, Takala (1985) and Milton and Meara (1998) do not make use of the 2K VLT and their subjects have different language profiles from our learners. Variation in vocabulary studies is extremely sensitive to the context and methodological issues involved in the investigation.

\section{RQ 2. Gender variation in types of motivation towards the foreign language}

The research on this issue points to the following findings: (1) learners achieve scores near the maximum level of extrinsic and intrinsic motivation; (2) levels of extrinsic motivation are higher than levels in intrinsic motivation in both groups, (3) females are more intrinsically and extrinsically motivated than males; yet, statistically significant differences are only identified regarding the intrinsic type of motivation; (4) more homogeneous findings concerning extrinsic rather than intrinsic motivation in each gender; and (5) lack of correlation between intrinsic and extrinsic motivation both for males and females.

It is interesting to observe that both males and females show similar patterns in the standard deviation in both types of motivation, being the deviation for the intrinsic type of motivation higher than the one for the extrinsic type. In extrinsic motivation, there is almost an identical result in both genders, both in means, maximum and minimum scores, and standard deviation, being this last one close to 0 . To put it in another way, for both groups of learners it seems that the relevance of external reasons why they have to learn a foreign language is similar, and also higher than internal desires.

On the other hand, the fact that females are more intrinsically motivated than males means that females think that English is more attractive, pleasant, interesting or nicer than boys do. This female advantage in intrinsic motivation supports the results of a large body of studies, such as those mentioned in the review of the literature above (e.g., Dabbagh and Khajehpour 2011; Dörnyei and Csizér 2002; Henry 2012; Henry and Apelgren 2008). However, when the focus is placed on the context, it seems that, differently from some studies conducted with CLIL students (Baker and MacIntyre 2000; Lasagabaster 2014; Merisuo-Storm 2007), no waning effect of CLIL over motivation levels is perceived in the present study since, at least in intrinsic motivation, girls present this statistically significant superiority. As Lasagabaster and Sierra (2009) note, a possible interpretation of this result could be that the above-mentioned levelling effect is lost in weak versions of CLIL. We should remember that the type of CLIL implemented for our group of students can be considered a weak one, what in this case means that only part of a subject, rather than the whole curriculum, has been taught via English. A longitudinal study that measures the evolution of the levels of motivation of these students across different levels can help shed light on this issue.

Finally, it is also interesting to note the lack of correlation between intrinsic and extrinsic motivation in both genders. This finding could make us think of the fact that, being independent of each other, only one type of motivation could have an effect on language acquisition results, while the other could remain unrelated. In the following lines, we will discuss on the findings of the relationship between these two types of motivation and vocabulary size. 
RQ 3. Relationship between motivation towards EFL and receptive vocabulary size

As found in the literature, we could expect a certain positive relationship between learners' level of motivation towards the foreign language and their performance in learning this foreign language. Yet, no correlation is identified between the results of both genders in the $2 \mathrm{~K}$ VLT and their levels of intrinsic and extrinsic motivation. Although girls are more intrinsically motivated than boys and intrinsic motivation is found to be the best predictor of results in language learning, as concluded by Bernaus and Gardner (2008), in this study it seems that vocabulary learning results are not affected by this type of motivation at all.

In interpreting this lack of relationship between motivation and vocabulary size, we have to bring back here the idea posed by Laufer and Paribakht (1998) or Nation (2001) concerning the different nature of productive and receptive vocabulary. Producing vocabulary is a more demanding task than receiving it and the former could be more closely connected to motivation as a desire of wanting to transmit a message is necessarily required in production but not in reception. Differences in the results are not only suggested for productive and receptive tasks, but also for different types of productive tasks and different types of receptive tasks (Jiménez Catalán and Ojeda Alba, 2009; Sunderland 2000). For instance, boys have been found to be superior in multiple-choice tasks and girls in extended writing tasks (Sunderland, 2000: 212-213).

\section{CONCLUSION}

This study finds no statistically significant results on gender differences in vocabulary size. A statistically significant bigger level of intrinsic motivation is identified in females versus males. In no case a connection is found between receptive vocabulary size and intrinsic and extrinsic motivation.

As explained above, in many cases a waning effect of CLIL in gender variation regarding motivation has been adduced. The results obtained in the present study are not totally against this waning effect, as it has been reported in the literature that it is not present in settings where CLIL is weakly implemented, as ours.

The context (CLIL) or the type of vocabulary task (receptive) can be reported as variables that interact with learners' gender and motivation. However, it is not so clear that this interaction has some effect on receptive vocabulary size. Therefore, as stated above, one cannot lose sight of the complexity involved in the interplay between motivation and vocabulary learning, as they should be understood and analysed as living or dynamic processes inextricably subject to considerable fluctuation (Tseng and Schmitt 2008; Zheng 2012). This conceptualization of the two factors opens the door to longitudinal research that could provide evidence on each of these two issues and its behaviour.

In any case, among others, further research should set up follow-up mechanisms to study both variables within a CLIL context. A closer examination of the behaviour of both factors would help understand their connection or lack of it. In a different line, the relationship between motivation and receptive vocabulary knowledge should be complemented with studies on motivation and productive vocabulary knowledge so as to identify the 
role played by the type of vocabulary learning examined. It would be advisable to include different types of productive and receptive tasks in further investigation.

Research on affective and motivational aspects together with research on this sensitive field of vocabulary acquisition is of crucial relevance for teaching. Knowledge on types of vocabulary acquisition will contribute to a better implementation of foreign language methodologies that promote vocabulary learning from a variety of ways.

\section{Acknowledgements}

We are very thankful to our statistician Montserrat San Martin for providing us with very valuable statistical assistance and helpful insights into data interpretation. Any remaining errors are our own.

\section{REFERENCES}

Agustín Llach, Ma . P. and M. Terrazas Gallego. 2012. "Vocabulary knowledge development and gender differences in a second language". ELIA 12: 45-75.

Anglada, L. and D. Banegas, 2012. "Views on motivation and autonomy in ELT." Selected Papers from the XXXVII FAAPI Conference. San Martín de los Andes, Argentina, 20-22 September 2012.

Azarnoosh, M., and P. BiRJANDi. 2012. “Junior high school students' L2 motivational self system: Any gender differences?” World Applied Sciences Journal 20, 4: 577-584.

Baker, S. C. and P. D. Macintyre. 2000. "The effects of gender and immersion on communication and second language orientations". Language Learning 50: 311-347.

Bernaus, M. and R. C. GARDNER. 2008. "Teacher motivation strategies, student perceptions, student motivation, and English achievement". The Modern Language Journal 92, 3: 387-401.

BRUton, A. 2011. "Is CLIL so beneficial or just selective? Re-evaluating some of the research". System 39: 523-532.

Cenoz, J., Genesee, F., and D. GorTer. 2013. "Critical analysis of CLIL: taking stock and looking forward". Applied Linguistics 13: 1-21.

CSIZÉR, K. and Z. DÖRNYEI. 2005. "The internal structure of language learning motivation and its relationship with language choice and learning effort". Modern Language Journal 89:19-36.

DabBagh S. and M. KhaJehPour. 2011. "Attitudes and motivation in learning English as second language in high school students". Procedia - Social and Behavioral Science 15: $1209-1213$.

Dalton-Puffer C., Nikula, T. and U. Smit, eds. 2010. Language Use and Language Learning in CLIL Classrooms. Amsterdam: Benjamins. 
DaLton-Puffer, C. 2011. "Content-and-Language Integrated Learning: From practice to principles?" Annual Review of Applied Linguistics 31: 182-204.

Dalton-Puffer, C. and U. Smit, eds. 2007. Empirical Perspectives on CLIL Classroom Discourse. Frankfurt: Peter Lang.

DeCI, E.L. and R. M. Ryan, 1985. Intrinsic Motivation and Self-Determination in Human Behavior. New York: Plenum Publishing Co.

Doiz, A., Lasagabaster, D. and J. M. Sierra, 2014. "CLIL and motivation: the effect of individual and contextual variables". Language Learning Journal 42: 209-224.

DörnYeI, Z. 2005. The Psychology of the Language Learner: Individual Differences in Second Language Acquisition. Mahwah, NJ.: Lawrence Erlbaum.

.2009. "The L2 motivational self system." Motivation, Language Identity and the L2 Self. Eds. Z. Dörnyei Z. and E. Ushioda E. Bristol: Multilingual Matters. 92-142.

DörnYEI, Z. and K. Csizér. 2002. "Some dynamics of language attitudes and motivation: results of a longitudinal nationwide survey". Applied Linguistics 23: 421-462.

Dörnyei, Z. and E. Ushioda, eds. 2009. Motivation, Language Identity and the L2 Self. Bristol: Multilingual Matters.

Dörnyei, Z., Csizér, K. and N. Németh. 2006. Motivation, Language Attitudes and Globalisation: a Hungarian Perspective. Multilingual Matters Clevedon.

FAN, M. 2000. "How big is the gap and how to narrow it? An investigation into the active and passive vocabulary knowledge of L2 learners". RELC Journal 31: 105-119.

FERNÁNDEZ FonTECHA, A. 2010. "First steps of CLIL in a Spanish monolingual community: The case of La Rioja." CLIL in Spain: Implementation, Results and Teacher Training. Eds. Y. Ruiz de Zarobe and D. Lasagabaster. Newcastle, UK: Cambridge Scholars Publishers. 79-94.

FORTANET-Gómez, I. 2013. CLIL in Higher Education. Towards a Multilingual Language Policy. Bristol: Multilingual Matters.

GabrYś-Barker, D. and J. Bielska, 2013. The Affective Dimension in Second Language Acquisition. Bristol: Multilingual Matters.

Gardner, R. C. and W. E. Lambert, 1972. Attitudes and Motivation in Second Language Learning. Rowley, MA: Newbury.

Golberg, H., Paradis, J. and M. Crago. 2008. "Lexical acquisition over time in minority first language children learning English as a second language". Applied Psycholinguistics 29: 41-65.

HenRY, A. 2012. “Gender differences in compulsory school pupils' L2 self-concepts: A longitudinal study.” System 37, 2: 177-193.

Henry, A. and B. A. Apelgren. 2008. "Young learners and multilingualism: A study of learner attitudes before and after the introduction of a second foreign language to the curriculum". System 36, 4: 607-623. 
Heras, A. and D. Lasagabaster, in press. "The impact of CLIL on affective factors and vocabulary learning”. Language Teaching Research.

HuAng, K. 2011. "Motivating lessons: A classroom-oriented investigation of the effects of content-based instruction on EFL young learners' motivated behaviours and classroom verbal interaction". System 39, 2: 186-201.

Huang, S., Eslami, Z. R. and V. Wilson. 2012. "The Effects of Task-involvement Load on L2 incidental Vocabulary Learning: A Meta-Analytic Study”. Modern Language Journal 96, 4: 544-557.

Jiménez Catalán, R. M. and J. Ojeda Alba. 2009. “Girls’ and Boys' Lexical Availability in EFL”. International Journal of Applied Linguistics 158: 57-76.

JimÉnez CATALÁn, R. M. and Y. Ruiz De Zarobe. 2009. “The receptive vocabulary of EFL learners in two instructional contexts: CLIL versus non-CLIL." Content and language integrated learning. Evidence from research in Europe. Eds. R. M. Jiménez Catalán and Y. Ruiz de Zarobe. Bristol: Multilingual Matters. 81-92.

Jiménez CATAlán, R. M., Ed. 2010. Gender Perspectives on Vocabulary in Foreign and Second Language. Basingstoke: Palgrave Macmillan.

Jiménez CATAlán, R. M., Ruiz de Zarobe, Y., and J. Cenoz. 2006. "Vocabulary profiles in English as a subject and as a vehicular language". VIEWZ 15, 3: 23-27.

KIM, Y. 2008. "The role of task-induced involvement and learner proficiency in L2 vocabulary acquisition". Language Learning 58, 2: 285-325.

LASAgabaster, D. 2003. Trilingüismo en la enseñanza. Actitudes hacia la lengua minoritaria, la mayoritaria y la extranjera. Lleida: Milenio Educación.

.2011. "English achievement and student motivation in CLIL and EFL settings". Innovation in Language Learning and Teaching 5: 3-18.

. 2014. "The impact of gender and English proficiency on attitudes towards English-medium instruction". Rivista di Psicolinguistica Applicata/Journal of Applied Psycholinguistics 14: 67-82.

Lasagabaster, D. and J. M. Sierra. 2009. "Language attitudes in CLIL and traditional EFL classes". International CLIL Research Journal 1, 2. 14 Jan. 2014. http://www. icrj.eu/12/article1.html.

LAUFER, B. and J. HulstiJn. 2001. "Incidental vocabulary acquisition in a second language: the construct of task-induced involvement". Applied Linguistics 22: 1-26.

LAufer, B. and T. S. PARIBAKht. 1998. "The relationship between passive and active vocabularies: Effects of language learning context”. Language Learning 48: 365-391.

Llinares, A., Morton, T., and R. WhitTaker, 2012. The Roles of Language in CLIL. Cambridge: CUP. 
Mearns, T. L. 2012. "Using CLIL to enhance pupils' experience of learning and raise attainment in German and health education: a teacher research project". Language Learning Journal 40, 2: 175-192.

Merisuo-Storm, T. 2007 "Pupils' attitudes towards foreign-language learning and the development of literacy skills in bilingual education". Teaching and Teacher Education 23: 226-235.

Milton, J. and P. Meara. 1998. “Are the British really bad at learning foreign languages?" Language Learning Journal 18: 68-76.

MurTaGH, L. 2007. "Out-of-school use of Irish, motivation to learn the language and proficiency in immersion and subject-only post-primary programmes". International Journal of Bilingualism and Bilingual Education 10,4: 428-453.

Nation, P. 2001. Learning Vocabulary in Another Language. Cambridge: Cambridge University Press.

Noels, K. A., Pelletier, L. G., Clément, R. and R. J. Vallerand, 2000. "Why are you learning a second language? Motivational orientations and Self-Determination Theory". Language Learning 50: 57-85.

Ruiz de Zarobe, Y. and R. M. JimÉnEZ CATALÁn, eds. 2010. Content and Language Integrated Learning: Evidence from Research in Europe. Bristol: Multilingual Matters.

Schmitt, N., Schmitt, D., and C. Clapham. 2001. "Developing and exploring the behaviour of two new versions of the Vocabulary Levels Test". Language Testing 18, 1: 55-88.

SeikKula-Leino, J. 2007. "CLIL learning: achievement levels and affective factors". Language and Education 21, 4: 328-341.

Sunderland, J. 2000. "Issues of language and gender in second and foreign language education". Language Teaching 33, 4: 203-233.

TAKALA, S. 1985. "Estimating students' vocabulary sizes in foreign language teaching. Practice and problems in language testing." Practice and Problems in Language Testing. Eds. V. Kohonen, H. van Essen, and C. Klein-Braley. Tampere: Finnish Association for Applied Linguistics. 157-65.

ThorndiKe, E. and I. Lorge. 1944. The Teacher's Word Book of 30,000 Words. New York Teachers College: Columbia University.

Tseng, W-T. and N. SchmitT. 2008. "Toward a Model of Motivated Vocabulary Learning: A Structural Equation Modeling Approach”. Language Learning 58, 2: 357-400.

West, M. 1953. A General Service List of English Words. London: Longman.

Yu, B., and D.A. WATKINS. 2008. "Motivational and cultural correlates of second language acquisition: an investigation of international students in the universities of the people's Republic of China". Australian Review of Applied Linguistics 31, 2: 17.1-17.22.

ZHENG, Y. 2012. "Exploring long-term productive vocabulary development in an EFL context: The role of motivation". System 40: 104-119. 
APPENDIX 1: 2,000-WORD FREQUENCY-BAND FROM THE RECEPTIVE VERSION OF THE VOCABULARY

LEVELS TEST (2K VLT) (SCHMITT, SCHMITT AND CLAPHAM 2001)

\begin{tabular}{|c|c|c|c|}
\hline & EXAMPLE & & EXAMPLE \\
\hline $\begin{array}{l}1 \text { business } \\
2 \text { clock } \\
3 \text { horse } \\
4 \text { pencil } \\
5 \text { shoe } \\
6 \text { wall }\end{array}$ & $\begin{array}{l}\text { part of a house } \\
\text { animal with } 4 \text { legs } \\
\text { something used for writing }\end{array}$ & $\begin{array}{l}1 \text { business } \\
2 \text { clock } \\
3 \text { horse } \\
4 \text { pencil } \\
5 \text { shoe } \\
6 \text { wall }\end{array}$ & $\begin{array}{l}\text { _ _ _ part of a house } \\
-3 \text { _ animal with } 4 \text { legs } \\
\text { _ } 4 \text { _ something used for writing }\end{array}$ \\
\hline $\begin{array}{l}1 \text { coffee } \\
2 \text { disease } \\
3 \text { justice } \\
4 \text { skirt } \\
5 \text { stage } \\
6 \text { wage }\end{array}$ & $\begin{array}{l}\text { money for work } \\
\text { a piece of clothing } \\
\text { using the law in the right way }\end{array}$ & $\begin{array}{l}1 \text { adopt } \\
2 \text { climb } \\
3 \text { examine } \\
4 \text { pour } \\
5 \text { satisfy } \\
6 \text { surround }\end{array}$ & $\begin{array}{l}\text { go up } \\
\text { look at closely } \\
\text { be on every side }\end{array}$ \\
\hline $\begin{array}{l}1 \text { choice } \\
2 \text { crop } \\
3 \text { flesh } \\
4 \text { salary } \\
5 \text { secret } \\
6 \text { temperature }\end{array}$ & $\begin{array}{l}\text { heat } \\
\text { meat } \\
\text { money paid regularly for doing a job }\end{array}$ & $\begin{array}{l}1 \text { bake } \\
2 \text { connect } \\
3 \text { inquire } \\
4 \text { limit } \\
5 \text { recognize } \\
6 \text { wander }\end{array}$ & $\begin{array}{l}\text { join together } \\
\text { walk without purpose } \\
\text { keep within a certain size }\end{array}$ \\
\hline $\begin{array}{l}1 \text { cap } \\
2 \text { education } \\
3 \text { journey } \\
4 \text { parent } \\
5 \text { scale } \\
6 \text { trick }\end{array}$ & $\begin{array}{l}\ldots \ldots \text { teaching and learning } \\
\text { numbers to measure with } \\
\text { going to a far place }\end{array}$ & $\begin{array}{l}1 \text { burst } \\
2 \text { concern } \\
3 \text { deliver } \\
4 \text { fold } \\
5 \text { improve } \\
6 \text { urge }\end{array}$ & $\begin{array}{l}\text { break open } \\
\text { make better } \\
\text { take something to someone }\end{array}$ \\
\hline $\begin{array}{l}1 \text { attack } \\
2 \text { charm } \\
3 \text { lack } \\
4 \text { pen } \\
5 \text { shadow } \\
6 \text { treasure }\end{array}$ & $\begin{array}{l}\text { gold and silver } \\
\text { pleasing quality } \\
\text { not having something }\end{array}$ & $\begin{array}{l}1 \text { original } \\
2 \text { private } \\
3 \text { royal } \\
4 \text { slow } \\
5 \text { sorry } \\
6 \text { total }\end{array}$ & $\begin{array}{l}\text { first } \\
\text { not public } \\
\text { all added together }\end{array}$ \\
\hline $\begin{array}{l}1 \text { cream } \\
2 \text { factory } \\
3 \text { nail } \\
4 \text { pupil } \\
5 \text { sacrifice } \\
6 \text { wealth }\end{array}$ & $\begin{array}{l}\text { part of milk } \\
\text { a lot of money } \\
\text { person who is studying }\end{array}$ & $\begin{array}{l}1 \text { ancient } \\
2 \text { curious } \\
3 \text { difficult } \\
4 \text { entire } \\
5 \text { holy } \\
6 \text { social }\end{array}$ & $\begin{array}{l}\text { not easy } \\
\text { very old } \\
\text { related to God }\end{array}$ \\
\hline
\end{tabular}


APPENDIX 2. LIKERT ADAPTED FROM GARDNER'S (1985) A/MTB SCALE

\begin{tabular}{|l|l|l|l|l|l|l|l|l|}
\hline Necesario & & & & & & & & Innecesario \\
\hline Feo & & & & & & & & Bonito \\
\hline Difícil & & & & & & & & Fácil \\
\hline Atractivo & & & & & & & & No atractivo \\
\hline Agradable & & & & & & & & Desagradable \\
\hline Poco importante & & & & & & & & Importante \\
\hline Inútil & & & & & & & & Útil \\
\hline Interesante & & & & & & & & Aburrido \\
\hline
\end{tabular}

